\title{
Chemical Weathering of Basement Basalt Causing Massive Landslide in Malin Village of Pune District in Maharastra, India: Lesson from Ethiopia
}

\author{
BB Mishra*, Solomon Estifanos, Kibebew Kibret, Lemma Wogi, Bobe Bedadi and Ayele Akuma \\ School of Natural Resources Management \& Environmental Sciences, Haramaya University, Ethiopia
}

Submission: May 15, 2017; Published: June 16, 2017

"Corresponding author: BB Mishra, School of Natural Resources Management \& Environmental Sciences, Haramaya University, P0 Box 138, Dire Dawa, Ethiopia, Email: bbmsoil@rediffmail.com

\begin{abstract}
Massive landslide in Malin village of Pune (India) on $14^{\text {th }}$ July 2014 was probably due to chemical weathering (reduction) of underground (basement) basalt at its bottom forming non-sticky mud under continued wetting environment with stored water through vertical cracks in rocks. Basalt at basement undergoes chemical reduction and probably microbial transformation with lapses of time under wet environment. This disastrous incidence of Malin, which is situated on basalt landscape, is a strong message to other parts of the world too for suitable preventive measures. Mumbai in India may fall in such risk zone. Ethiopia in this respect also seems to be sensitive with other African countries. Detailed investigation is desired to validate the truth in order to develop a strategic planning. This exploratory research is effective in laying the ground work that will lead to form the basis of systematic conclusive research. Even the farmer's suicidal case could be examined, if it relates to early drying of their soils possessing vertic properties.
\end{abstract}

Keywords: Basalt landscape; Basement basalt; Chemical weathering; Reduction process; landslide; Farmer's suicidal issues

\section{Introduction}

Evidence often fails to prove the truth that leads conflicts in scientific decision. On 30 July 2014, while residents in Malin village under Ambegaon taluka of Pune (Maharastra) in India were asleep, a landslide caused sudden hit early in the morning during heavy rain following a casualty of many men and women (total around 150). Such a dreadful incidence led to speculate about the possible causes in the Indian media to ascertain the cfacts behind causes and triggers of the Malin landslide. It was strongly argued that this area was affected by very strong monsoon rainfall for in the two days prior to the landslide. Even the NASA TRMM landslide warning tool highlighted this as a zone that was very susceptible to landslides due to incident of rainfall as in media. Further speculation says that as much as $600 \mathrm{~mm}$ of precipitation well before this disaster might have caused this ugly consequence. It was also flashed in media that the dam at Dimbhe, a few kilometers downstream might be a possible factor. There was also discussion about the role of development and deforestation, which might be far more important. The landslide appeared to be a mudslide in deeply weathered soils, but there was no evidence of involvement of large amounts of bedrock. Meanwhile, the geology map prepared by the Geological Survey of India indicated that structurally the area is highly disturbed and subjected to faulting. It was further observed that the watershed is entirely covered with basalt rock.

Further speculation says that the landslide occurred in Malin village was triggered due to many human induced factors the close association with of heavy rainfall. One of the main factors responsible for the landslide in Malin village was apprehended due to the Padkai scheme of Government which is providing plots to the resident for farming purposes with terracing the hill slopes. Media also says that some agricultural officials were warned and even punished based on certain issues apprehended.

Based on speculations, some preventive measures were flashed in news papers such as

a. Water being the main causative agent must be prevented from entering into the affected area.

b. Landslides being the natural disaster cannot be prevented but its impacts could be minimized by taking timely preventive measures.

c. The magnitude of the mass movement can be minimized by construction of an efficient drainage network. 
d. Landslides may be minimized by engineering technology which involves provision of surface as well as subsurface drainage, removal of unstable slope material and modification of unstable slope to stability, lastly construction of retaining walls in the periphery of the area where Padkai is developed.

e. Soil erosion being the causative factor may be reduced by increasing the vegetative growth in the sloping areas.

f. Public awareness about changing the agricultural practices as well as controlling the human induced factors. However, Pooja \& Mane [1] studied the landslide zones of nearby areas of Malin village using GIS techniques to find some concrete answer.

The present report is exploratory towards an approach to disclose the hidden and mysterious fact behind the disastrous incidence of landslide already occurred in Malin village $\left(19^{\circ} 9^{\prime} 40^{\prime \prime} \mathrm{N} 73^{\circ} 41^{\prime} 18^{\prime \prime} \mathrm{E}\right)$ in India in 2014 and an awareness thereof towards strategies for concrete initiatives to safeguard the life, construction, properties and environment against any such future incidence on basalt rich landforms in India, Ethiopia and other parts of the globe.

\section{Preliminary Survey}

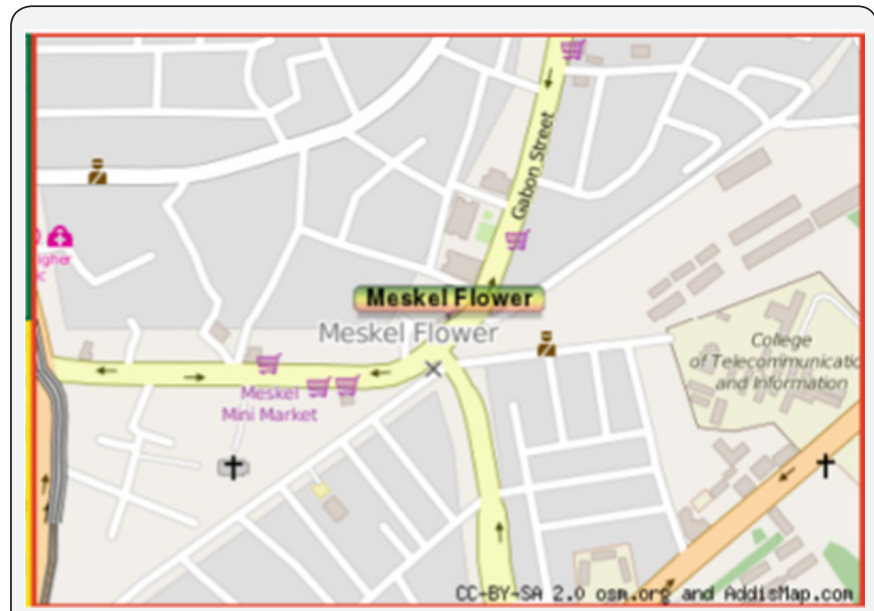

Figure 1: Meskel Flower in Addis Ababa, Ethiopia.

First time in 2002, during field survey under Hirna watershed in Ethiopia $\left(9^{\circ} 13.177^{\prime} \mathrm{N}, 41^{\circ} 4.955^{\prime} \mathrm{E}\right.$ and $9^{\circ} 13.610^{\prime} \mathrm{N}$ and $41^{\circ} 5.129^{\prime} \mathrm{E}$ ), the first two authors (Mishra and Kibebew) identified the mountain water stored within the basalt mountain [2]. During recent past Mishra [3] reported that the massive landslide on July $30^{\text {th }}, 2014$ in Malin village of Pune in Maharastra was probably due to chemical reduction of lower basalt (basement) forming mud on loosening at the bottom of the basaltic stratum subject to washing through heavy rains. On $17^{\text {th }}$ March 2017, while travelling to Zuway area of south Ethiopia, a typical vertical rock profile of basalt was observed around Masholoke (Figure 1) near Meskel Flower of Addis Ababa (Latitude 08.9957N; Longitude 38.7667E) as depicted in Figures 1-5. On visual examination, Figure 2 indicates a complete profile of a basalt rock showing vertical crack from its upper top to bottom (basement) either in continuum or broken. At the basement, the basalt gets reduced to whitish material followed by reddish muddy material that seems to be a buried soil below the whitish materials underlying the unweathered or consolidated basalt.

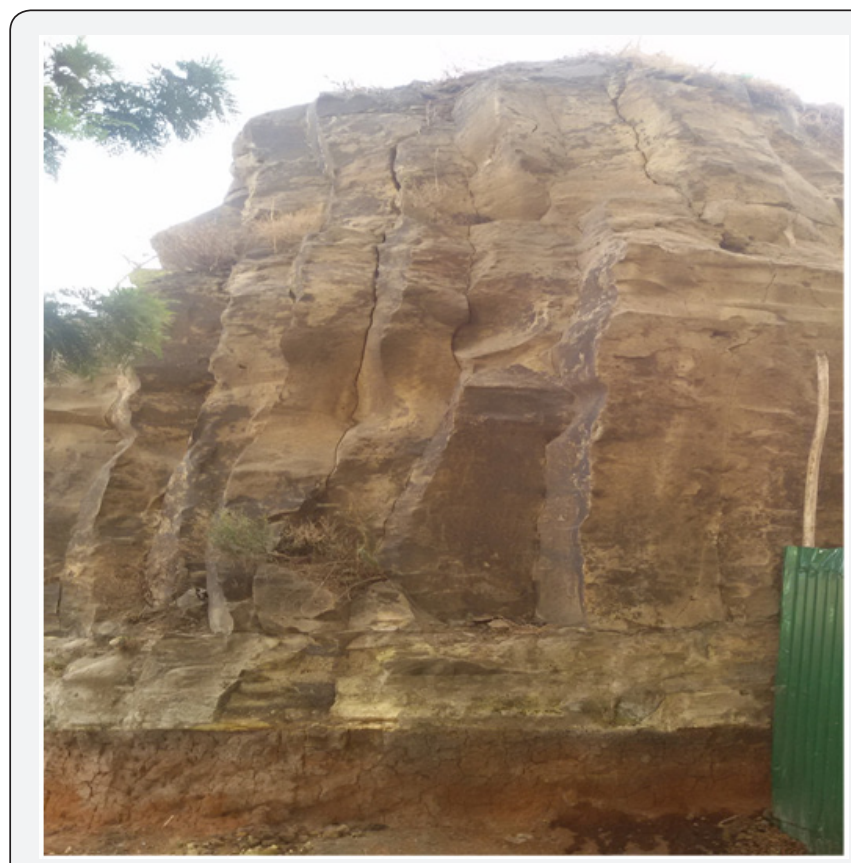

Figure 2 :Weathering of basalt at the bottom under continued wetness caused by accumulated rainwater through the vertical space or cracks in basalt rock.

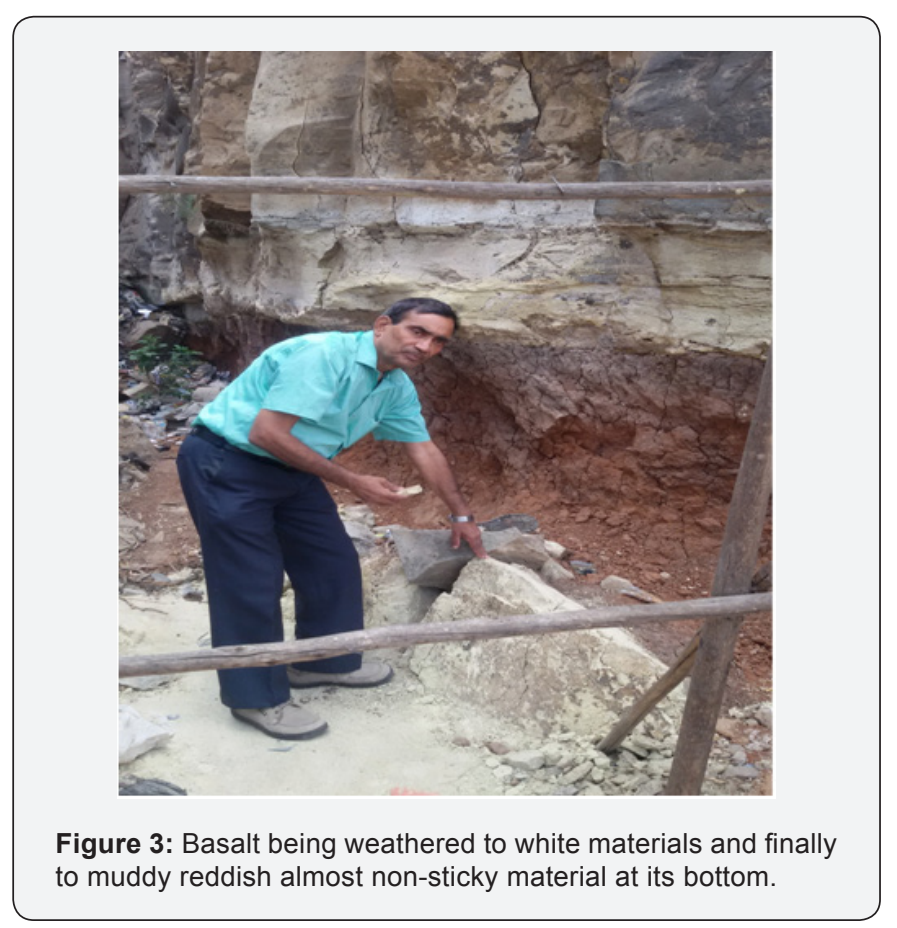

Figure 3 is simply a close display of whitish and muddy layers being the successive weathering products of basal in a weathering environment, while Figure 4 shows the weathered materials 
(mud basalt) at basement/bottom. It is this basement weathered basalt that is subject to removal or washing gradually with water leaving its space to be filled by the overlying consolidated basalt causing expected landslide. Figure 5 is the generalized view of the surface weathering of basalt in open ecosystem resulting in soil formation at the top followed by yellowish white portion of weathered basalt (regolith) and pure basalt (unweathered) at the bottom (basement). We recommend for undertaking further detailed investigation on site-specific basis to re-confirm in order to approve the present observations.
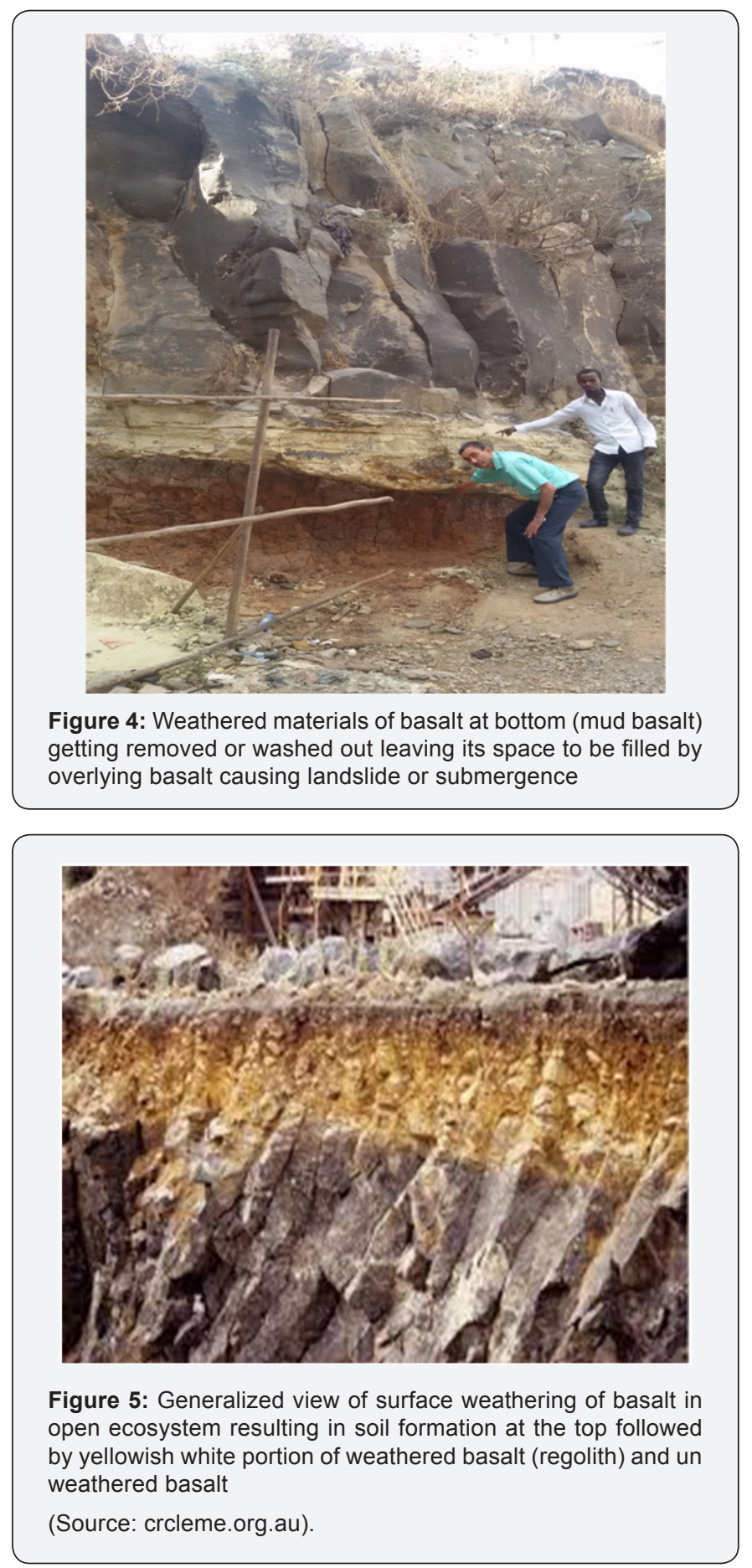

\section{Result and Discussion}

Basalt is usually grey to black in colour and weathers to brown or rust-red colour under the influence of oxidation to limonite, haematite and other iron oxides and hydroxides. Basalt in general contains about $45 \% \mathrm{SiO}_{2}, 14 \% \mathrm{Al}_{2} \mathrm{O}_{3}, 12 \% \mathrm{FeO}, 1.0$ $\% \mathrm{TiO}_{2}$, with appreciable amount of $\mathrm{CaO}$ and $\mathrm{MgO}$ contents by weight. Templeton et al. [4] cultured $\mathrm{Fe}^{2+}$ and $\mathrm{Mn}^{2+}$ oxidizing bacteria from weathered submarine basalts. The reduced iron $\left(\mathrm{Fe}^{2+}\right)$ and manganese $\left(\mathrm{Mn}^{2+}\right)$ present in basaltic rocks provide potential energy sources for bacteria. Some $\mathrm{Fe}^{2+}$-oxidizing bacteria cultured from iron-sulfide surfaces are also able to grow with basaltic rock as a source of $\mathrm{Fe}^{2+}$ [5]. Basalt weathers relatively fast as compared to other rocks. The iron-rich minerals in basalt weather oxidize rapidly in water and air and impart staining the rock somewhat brownish to reddish coloration. However, calcium released during chemical weathering from basalt combines with $\mathrm{CO}_{2}$ from the surrounding environment thereby forming $\mathrm{CaCO}_{3}$. Jeremy [6] opined that the underwater basalt deposits have the added benefit of the water serving as a barrier to the re-release of $\mathrm{CO}_{2}$ into the atmosphere.

The weathered basement materials, in the present study, indicated reddish brown colour (5YR4/3) with sandy loam fine texture (sand $79 \%$, silt $9 \%$ and clay $12 \%$ salty clay) virtually negligible or no stickiness and thus might be supporting these materials to be easily washed out with water. However, this wet material resembles red soil (buried) and become hard on drying, but friable on moistening (Figure 6). The $\mathrm{pH}$ of this mud sample of weathered basalt was 5.6 to 5.8 (acidic), while organic carbon content was 0.485 to 0.558 percent. This simply implies that the weathered basalt was devoid of basic cations, though basalt is basic in nature. However, this material contains appreciable amount of organic carbon probably because of expected microbiological association with mud basalt as well as inherent properties of basalt to capture carbon Robert et al. [7].

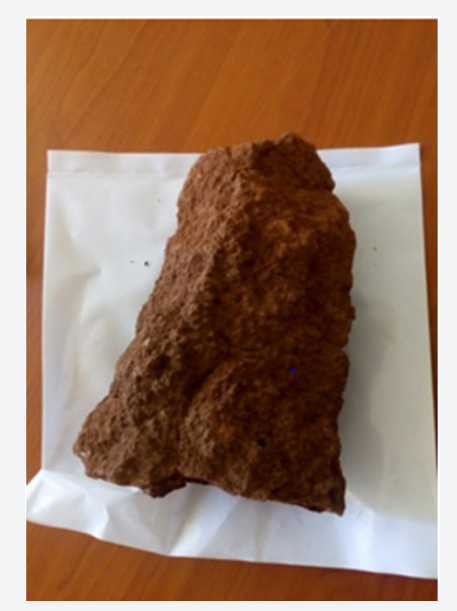

Figure 6: Weathered basalt at basement (Non-sticky, friable when moist but slightly hard when dry, organic carbon 0.485 to $0.5584 .8 \%$ ). 
With reference to the basalt weathering at the surface and subsequent formation of soil under the specific soil forming process with a particular set of factors (Figure 4), the weathering of underground /basement basalt is purely chemical under reduced condition for a long period of time followed by microbiological interactions [8]. It is obvious that the rock below the basalt (basement) would be either granite or sandstone (quartz dominating) as these two are generally least reducing.

The heavy rain might have washed such basaltic mud out from the bottom causing the houses to set buried. This indicates that the truth of this evidence might also be a possible threat in future to many of multistoried buildings and other constructions at Mumbai and other places across the world where landscape possesses the base of extrusive rock particularly basalt [3]. In Vidarbha zone of Maharashtra in India, soils on the surface are developed mostly on basalt, which facilitates rain or stored water to move down through the cracks of basalt and, thus, the soils get dried up soon, though basalt on weathering and transformation results into clay-rich soils with high cation exchange and high moisture retention capacity. If the soil indicates relatively high rate of drying, compared to certain reference, it may be because of more passage for water to move down through the cracks and thereby it may be a warning of landslide identical to Malin. A system approach through soil evaluation and land use planning could help in minimizing the expected suicidal case in this region even. Basalt is weather able, but relatively less erosive with high water holding capacity. If basalt contains zeolite, its water storage capacity would be increased as evident from reports of ICAR-NBSS \& LUP, Nagpur. Obviously, the issue of suicidal case in Maharastra may be mitigated or even minimized preferably by effective land use planning, if the suicidal causes relate to land quality and characteristics.

Michael et al. [9] earlier reported that the analysis of the solid samples of basalt indicated total reduction of $\mathrm{Fe}^{2+}$ in ilmenite and small degrees of reduction in olivine and pyroxene. $\mathrm{TiO}_{2}$ was also partially reduced to one or more oxides. Earlier works revealed that the microbial transformation of carbon, nitrogen and bio available metals (iron, manganese) may have significant impact on reduced elements in the basalt [8-11].

Based on evidence that makes the truth, it is apparent that suitable measures may be initiated across the globe where landscapes exit on basalt in order to avoid unseen consequences as experienced in Malin village in India. Even the issue of suicidal case in India needs to be examined with the nature and stage of weathering of basalt at its bottom (basement) in the aquifer. Such observations may help to develop a strategic plan to overcome the threats speculated any more in India and other countries of the world. Ethiopia and some other African countries may have identical situations and deserve sincere attention for the safeguard of life, properties and overall environment by validating the truth based on Ethiopian evidences particularly in highlands of basaltic origin.

\section{Acknowledgements}

Thanks to Hussein Namu, MSc student (Soil Science), Haramaya University, Ethiopia for assistance and Lemessa Amenu, Senior Technical Assistant, Soil Chemistry Laboratory, $\mathrm{HU}$, Ethiopia for laboratory assistance.

\section{References}

1. Pooja G, Mane SJ (2015) Landslides Zones of Nearby Areas of Malin Village, Pune District, Maharashtra Using GIS Techniques. International Journal of Science and Research 4(7): 443-448.

2. Gebrekidan H, Mishra BB, Kibret K (2006) Missing linkage in rainfallrunoff-soil water relationship for sustainable watershed development: A case study around Hirna, Eastern Ethiopia. Journal of Food, Agriculture \& Environment 4(1): 239-245.

3. Mishra BB (2015) Soil Science and Land Use Planning: Myth, Reality, Evidence and Challenge. EC Agriculture 1.3(2015): 140-148.

4. Templeton AS, Hubert S, Tebo BM (2005) Diverse Mn (II)-Oxidizing Bacteria Isolated from Submarine Basalts at Loihi Seamount. Geomicrobiology Journal 22 (3-4): 127-139.

5. Edwards KJ, Bach W, Rogers DR (2003) Geo microbiology of the Ocean Crust: A Role for Chemoautotrophic Fe-Bacteria. Biological Bulletin 204(2): 180-185.

6. Jeremy H (2010) Under water rocks could be used for massive carbon storage on America's East Coast. Mongabay.

7. Robert J. Rosenbauer, Burt Thomas, James L. Bischoff and James Palandri (2012) Carbon sequestration via reaction with basaltic rocks: Geochemical modeling and experimental results. Geochimica et Cosmochimica Acta 89, 116-133.

8. Ingram JC, Cortez MM, Bates DL, McCurry MO (2001) Reductive Dechlorination of Trichloroethylene and Carbon Tetrachloride at Iron oxides and Basalt Minerals. In ACS Symposium Series 778: 267-281.

9. Michael A. Gibson, Christian W. Knudsen, David J. Brueneman, Carlton C. Allen, Hiroshi Kanamori and David S. McKay (1994) Reduction of lunar basalt 70035: Oxygen yield and reaction product analysis. Journal of Geophysical Research:Planets. DOI: 10.1029/94JE00787.

10. Bach W and Edwards K J (2003). Iron and sulfide oxidation within the basaltic ocean crust: implications for chemolithoautotrophic microbial biomass production. Geochim. Cosmochim. Acta 67 3871-3887.

11. Templeton AS, Hubert S, Tebo BM (2005) Diverse Mn (II)-Oxidizing Bacteria Isolated from Submarine Basalts at Loihi Seamount. Geomicrobiology Journal 22(3-4): 127-139. 


\section{Your next submission with Juniper Publishers will reach you the below assets}

- Quality Editorial service

- Swift Peer Review

- Reprints availability

- E-prints Service

- Manuscript Podcast for convenient understanding

- Global attainment for your research

- Manuscript accessibility in different formats ( Pdf, E-pub, Full Text, Audio)

- Unceasing customer service

Track the below URL for one-step submission https://juniperpublishers.com/online-submission.php 